\title{
The exponence of caseless NPs in Moksha
}

\author{
Polina Pleshak ${ }^{*}$
}

\begin{abstract}
In this paper, I argue that the difference between indefinite- and definitedeclension genitives in Moksha (Uralic) is not in the semantic or referential characteristics of the nominals they mark (as the name suggests), but rather in the syntactic size of the nominals. I show that there is no one-to-one correspondence between the definiteness of a noun phrase and its marking. In particular, indefinitedeclension genitives can mark non-specific indefinite as well as specific definite noun phrases. At the same time, indefinite-declension genitives are number-neutral, while definite-declension genitives are specified for number. In contrast to indefinite-declension nominals, definite-declension ones also trigger possessive agreement on the head noun. I analyze indefinite-genitives as NPs and definitegenitives as DPs. Based on what is generally known about DPs, I make several predictions regarding the distribution of the genitives; two definite-declension genitives should be incompatible within one enclosing DP, while there should be no such restriction on the co-occurrence of an indefinite-declension genitive with either another indefinite-declension genitive or a definite-declension genitive. These predictions are borne out, and these new findings enrich the discussion of the ban on the co-occurrence of two DPs which are too close in the structure. More generally, my analysis supports the view that nominals of different structural size can coexist within one language.
\end{abstract}

Keywords. syntax; morphology; noun phrase structure; small nominals; genitive case; agreement; Moksha; Finno-Ugric; Uralic

1. Introduction. In this paper, I discuss two types of genitive markers in Moksha (ISO-639-3: mdf, Finno-Ugric, Uralic), $-n^{\prime}$ and $-t^{\prime} /-t^{\prime} n^{\prime} \partial n^{\prime}$. Traditional grammars describe them as representing indefinite and definite declensions respectively (Koljadenkov \& Zavodova 1962). While many indefinite noun phrases appear with the indefinite-declension marker, and most definite-declension nominals are definite, this is no more than a tendency, and there is no one-to-one correspondence between the definiteness of a noun phrase and its marking. Instead, what distinguishes nominals marked with the two different genitive suffixes are their syntactic properties. The difference between definite- and indefinite-declension nominals has to do with their structural size. In particular, I analyze phrases in the definite-declension genitive as DPs and phrases in the indefinite declension as nominals of a smaller size. This contrast allows us to make specific predictions about the properties of each type, and to test them using novel Moksha data. ${ }^{1}$

\footnotetext{
* I am grateful to my Moksha consultants, especially to Valentina Liskina, as well as to my fieldwork colleagues and friends who were helping me in the field, especially Maria Kholodilova. I am also grateful to my former and current advisors Svetlana Toldova, Ekaterina Lyutikova, Maria Polinsky, and Omer Preminger for discussions of my data and analysis at different stages of this project.

This research is supported by RFBR grant № 19-012-00627.

Author: Polina Pleshak, University of Maryland, College Park (ppleshak@umd.edu).

${ }^{1}$ My analysis is based on my own fieldwork conducted in the villages of Lesnoje Tsibajevo and Lesnoje Ardashevo (Republic of Mordovia, Russia) in 2014-2017 and on further remote work with the same consultants in 2018-2019.
} 
2. Background. This section provides the basics of Moksha nominal morphology and lists my main theoretical assumptions.

2.1. BASICS OF MOKSHA MORPHOLOGY. Moksha is a Mordvin language of the Finno-Ugric branch of the Uralic family, spoken in the Republic of Mordovia, Russia. As befits most FinnoUgric languages, Moksha has rich morphology, and rich nominal morphology in particular. Number, possession, definiteness, and case are expressed with special morphological affixes. In (1), the singular is expressed by a zero marker, while the plural marker is - $t$. In (2), the word vel'a 'village' combines with a possessive affix which encodes the person and number of the possessor. The contrast in (3) suggests that the suffix shown in (3b) encodes definiteness, and can thus be treated as a suffixal determiner. (See Simonenko 2017 for discussion of suffixal determiners in Finno-Ugric, Turkic and Mongolian.) Finally, noun phrases in different syntactic positions bear different case affixes. The contrast in (4) shows that the same definite singular non-possessed noun phrase bears distinct markers in subject and object position. Note that genitive marks both direct objects and possessors.

(1) NUMBER
a. vel' $\partial^{2}-\varnothing$ village- $\mathrm{SG}^{3}$
'a village'
POSSESSION
a. vel'ə-z'o village-1SG.POSS.SG 'my village'
DEFINITENESS
a. vel'ə-Ø
village-INDEF.SG
'a village'
b. vel'ə-s' village-DEF.SG
'the village'
b. vel'o-t
village-PL
'villages'
b. vel'ə-c'ə
village-2SG.POSS.SG
'your village'
CASE
a. vel'o-s' ocu village-DEF.SG[NOM] big 'The village is big'.
b. n'e-in'ə ocu vel'ə-t' see-PST.1SG.S.3SG.O big village-DEF.SG.GEN 'I saw the big village.'

Despite the general agglutinative nature of Moksha, where one affix is supposed to encode one category (e.g., possession or case, but not both), sometimes a single affix encodes several categories. Consider the contrast between classic agglutination in (5) on the one hand, and example (6) on the other, where number, case and definiteness are expressed by a single morpheme.

\footnotetext{
${ }^{2}$ Transcribing my examples, I follow the practical transcription proposed in (Toldova et al. 2018). This transcription

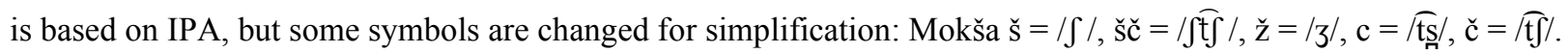
Symbol ' indicates palatalization.

${ }^{3}$ I use the following abbreviations: 1-3 - person, ADD - additive, ATTR - attributivizer, CONV - converb, DAT - dative, DEF - definite, DIM - diminutive, GEN - genitive, ILL - illative, IN - inessive, INDEF - indefinite, NOM nominative, NPST - non-past, O - object, PASS - passive, PL - plural, POS - positional, POSS - possession, PST - past, $\mathrm{S}$ - subject, $\mathrm{SG}$ - singular.
} 
ONE AFFIX - ONE CATEGORY

tarad-t-n'ə-n'

branch-PL-DEF-GEN

'[I saw $]$ the branches'.

(6) ONE AFFIX - SEVERAL CATEGORIES

tarad- $\mathrm{t}^{\prime}$

branch-DEF.SG.GEN

'[I saw] the branch'.

Because one and the same affix can encode several categories, traditional grammars of Moksha describe nominal morphology by organizing it into different declensions: indefinite, definite, and possessive (Koljadenkov \& Zavodova 1962). The possessive declension is used to express a relation of possession between the referent of the noun and that of the dependent noun phrase, as in (7). A more detailed discussion of this declension is beyond the scope of this paper.

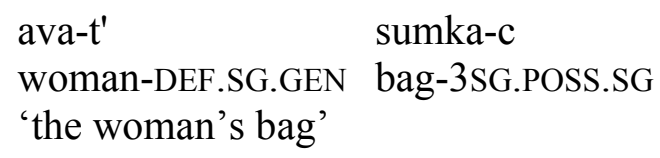

Here, I focus on the two other declensions, definite and indefinite. In section 3, I will show that these names do not reflect the properties of the respective declensions. First, the two declensions differ with respect to number encoding; number cannot be expressed in the definite declension. Second, only definite-declension noun phrases trigger possessive agreement on the head noun.

2.2. THEORETICAL BACKGROUND. I assume a hierarchical organization of the noun phrase, where functional projections responsible for number and referential properties of the noun phrase are located above the lexical noun (e.g., Abney 1987; Szabolcsi 1983; Alexiadou et. al 2007). Figure 1 illustrates this structure.

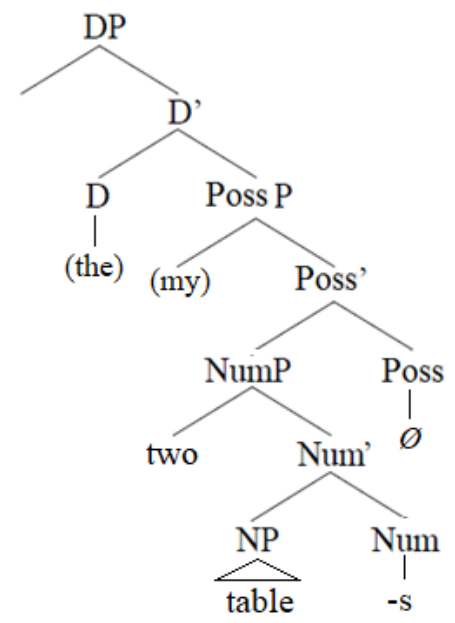

Figure 1. The structure of the noun phrase the two tables/my two tables ${ }^{4}$

For the present discussion, it is crucial that not all noun phrases have to be of full size (DP). Some of them may be no bigger than NumP or even NP (henceforth "small nominals";

\footnotetext{
${ }^{4}$ Some researchers do not distinguish PossP as a separate projection and assume that all relevant features are situated in D. The analysis here is compatible with either view.
} 
Pereltsvaig 2006). Being reduced in structure, the behavior of small nominals may differ from that of their DP counterparts. In particular, characteristics typical of full DPs, such as the triggering of agreement or the need for case licensing, are not expected of small nominals. Differences between DPs and small nominals will form the basis for the predictions discussed in section 4 .

Turning to case, I depart from the assumption that case is obligatorily assigned under agreement (Chomsky 2000). Instead, I adopt the configurational theory of case (Marantz 1991). The basic idea is that there are four types of case: (i) lexical (assigned by a functional head with relation to a theta-role); (ii) dependent (assigned to one of two DPs that stand in an asymmetric ccommand relation); (iii) unmarked (assigned to any DP that has not received case by (i)-(ii)), and (iv) default, which I leave aside here. The cases are assigned in a strict order beginning with (i). Setting aside the discussion of assignment of lexical and dependent case, let me focus on the assignment of unmarked case, primarily with respect to nominal dependents marked with genitive. Following Marantz (1991: 14), I assume that genitive is the realization of unmarked case in the nominal domain.

Although I argue that case assignment in Moksha is independent of agreement, I otherwise adopt the general probe-goal architecture of agreement (Chomsky 2000). A functional head has unvalued features and serves as a probe looking for a goal with matching features. Agreement probing is downward (specifically, within the c-command domain of the probe), and agreement happens with the structurally closest element that satisfies the probe's requirements. Crucially for my analysis, in order for the goal to be visible to the probe, the nominal projection must be of sufficient structural size to host the relevant features. If some of the layers are absent, the nominal does not qualify as a goal for the probe, is rendered invisible to the probe, and does not trigger agreement.

3. Syntactic properties of Moksha genitives. In this section, I show that there is no one-to-one correspondence between the definiteness of a noun phrase and its marking (declension), and thus the names of the relevant declensions are in some sense misleading. Since interpretation does not provide a reliable clue for the difference between the declensions, I examine the syntactic properties of nominals marked with each type of genitive.

3.1. DEFINITE INDEFINITES AND INDEFINITE DEFINITES. Table 1 shows a small part of the Moksha nominal paradigm. According to traditional grammars, Moksha has as many as 15 cases

(Evsevjev 1963; Koljadenkov \& Zavodova 1962; Feoktistov 1975; Plaksina 2002). I omit a large number of locative cases and other lexical cases which exist only in the indefinite declension (and I do not discuss their status vis à vis the case/adposition or case/derivational affix distinction). Here the focus is on the genitive, which exists in both indefinite and definite declensions.

\begin{tabular}{|c|c|c|c|}
\hline \multirow[t]{2}{*}{ Case } & \multicolumn{3}{|c|}{ Indefinite declension Definite declension } \\
\hline & SG & PL SG & PL \\
\hline \multicolumn{2}{|c|}{ Nominative $\varnothing$} & $-t /-t^{\prime}-s^{\prime}$ & $-\left(t^{\prime}\right) n^{\prime} \partial$ \\
\hline Genitive & $-\partial n^{\prime}$ & $-t^{\prime}$ & $-\left(t^{\prime}\right) n^{\prime} \partial-n^{\prime}$ \\
\hline Dative & $-\partial n^{\prime} d^{\prime} i$ & $-t^{\prime} i$ & $-\left(t^{\prime}\right) n^{\prime} \partial-n^{\prime} d^{\prime} i$ \\
\hline Ablative & $-d \partial /-t \partial /-d^{\prime} \partial /-t^{\prime} \partial$ & & \\
\hline Inessive & $-s \partial$ & & \\
\hline
\end{tabular}

Table 1. A fragment of the Moksha case paradigm (adapted from Kholodilova 2018)

As already mentioned, genitive encodes possessors and direct objects; it can also mark complements of postpositions. Therefore, one might expect indefinite possessors, direct objects and complements of postpositions to appear in the indefinite genitive, and definite possessors, direct 
objects and complements of postpositions to be marked with the definite genitive. However, the actual distribution of the relevant markers on possessors and direct objects does not meet this expectation.

Moksha has differential object marking (DOM), with objects contrasting in definiteness (Toldova 2017, 2018), cf. (8) and (9). However, indefinite objects appear in the nominative, not the genitive.

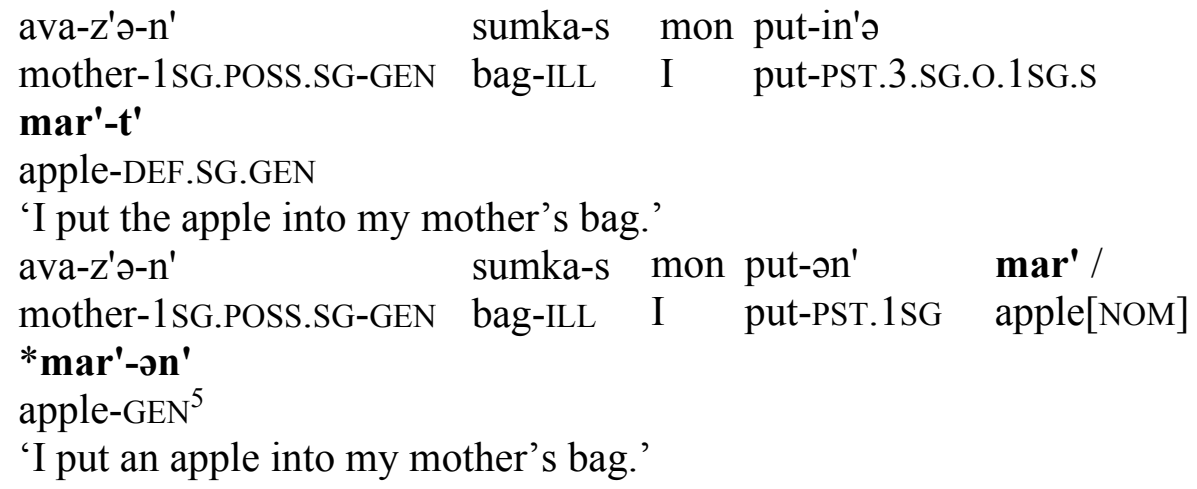

Thus, indefinite genitive cannot mark indefinite direct objects within the clausal domain.

Genitive is the case of possessors as well, or speaking more broadly, the case of adnominal dependents. We might expect to find indefinite possessors marked with indefinite genitive and definite possessors marked with indefinite genitive. However, the distribution of declension types is more complicated. Unmodified nominals marked with indefinite-declension genitive are never interpreted as specific; therefore, they cannot mark specific possessors, but rather, they encode generic possessors denoting a property. In (10), the possessor avan' cannot denote a specific woman who is the owner of the bag. The only way to interpret avan' is that as denoting the property of being made for women.

ava-n' sumka-s' pra-s'
woman-GEN bag-DEF.SG fall-PST.3SG
'The/A bag for women has fallen'.
*'A woman's bag has fallen.'

For the possessor to have a specific interpretation, some modification is needed. For example, if an indefinite pronoun modifies the possessor phrase, this phrase can be interpreted as specific. Unlike (10), the modified possessor in (11) can denote a specific woman:
kodamə
bəd'ə ava-n'
sumka-s' pra-s'
which INDEF woman-GEN bag-DEF.SG fall-PST.3SG
'A woman's bag has fallen.'
'One of the bags for women has fallen.'

However, even a non-specific possessor can appear in the definite-declension form. In (12), a free-choice indefinite pronoun modifies the possessor phrase, and the possessor is interpreted as non-specific. Yet the marking on the nominal is definite:

\footnotetext{
${ }^{5}$ Although I will argue against the view that $-n^{\prime}$ is an instance of the genitive case, in the examples below, I am glossing it as GEN, adopting the glossing conventions used in (Toldova et al. 2018).
} 


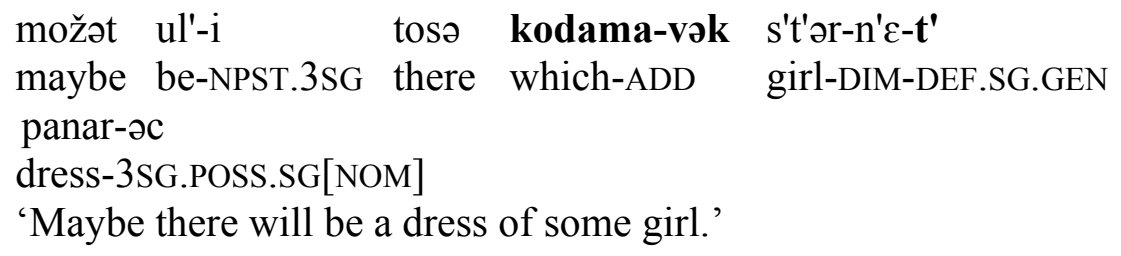

On the other hand, some definite nominal dependents cannot be marked with the definite-declension genitive. Although the noun phrase $t^{\prime} \varepsilon$ kizo- 'this year' in (13) is interpreted as definite, the sentence is ungrammatical when this noun phrase appears in the definite-declension genitive form. Note that the problem is not semantic; indefinite-declension marking makes the sentence felicitous (14).

\begin{tabular}{|c|c|c|c|}
\hline $\begin{array}{l}\text { *s'in' } \\
\text { thev }\end{array}$ & $\begin{array}{l}\text { mora-z' } \quad \text { kancercə } \\
\text { sing-PST.3.O.3PL.S concert.IN }\end{array}$ & $\begin{array}{l}\text { kodam } \\
\text { which }\end{array}$ & $\begin{array}{l}\text { bəd'ə } \\
\text { INDEF }\end{array}$ \\
\hline $\begin{array}{l}\text { kizə-t' } \\
\text { vear-D }\end{array}$ & $\begin{array}{ll}\text { morə-nc } \\
\text { F.SG.GEN } & \text { song-3SG.POSS.SG.G }\end{array}$ & & \\
\hline
\end{tabular}

Int.: 'At the concert they sang a song associated with this year.' (Pleshak \& Kholodilova 2018: 282)

(14) s'in' mora-s'-t' kancercə kodamə bəd'ə [t'c kizə-n'] morə they sing-PST.3-PL concert.IN which INDEF this year-GEN song 'At the concert they sang a song associated with this year.'

(Pleshak \& Kholodilova 2018: 282)

So far, I have shown that the referential status of the noun phrase does not determine its marking. In particular, specificity and definiteness do not guarantee that the respective noun will appear in the definite declension. An indefinite-declension genitive can appear even with specific definite possessors:
$\left[\mathbf{t}^{\prime} \boldsymbol{\varepsilon} \quad\right.$ ava-n']
sumka-s'
pra-s'
this woman-GEN bag-DEF.SG[NOM] fall-PST.3SG
'This woman's bag has fallen.'

These data suggest that a semantic account of the difference between the indefinite-declension genitive and the definite-declension genitive in the singular or plural would be on the wrong track.

3.2. MORPHOSYNTAX OF NOMINALS MARKED WITH THE TWO DECLENSION TYPES. Nominals in the definite declension differ from indefinite-declension nominals in two crucial respects: number distinctions and possessive agreement with the head noun.

Starting with the number distinctions, definite-declension genitives have two separate forms, singular (16a), and plural (16b).
a. vel'ə-t'
b. vel'ə-t-n'ว-n'
village-DEF.SG.GEN
village-DEF.PL-GEN
'of the village'
'of the villages'

In the indefinite declension, one and the same form is amenable to both singular and plural interpretation:
t' $\varepsilon$ ras't'en'ije-n' kor' $\varepsilon t^{\prime}-t^{\prime}-n^{\prime} \partial$
ašč-ij-t'
mon'
this plant-GEN root-PL-DEF.PL[NOM] be.situated-NPST.3-PL I.GEN
škatulka-sə-n
box-IN-POSS.1SG
'The roots of this plant / of these plants are in my box.' 
The absence of number distinction can be accounted for in two different ways. On the one hand, $-n$ ' forms can be viewed as ambiguous between the singular and plural, in which case the number feature is present and valued as [SG] or [PL], but the morphological marker is the same for both resulting in the syncretism of singular and plural genitive forms. Alternatively, indefinite-declension-genitive forms can be analyzed as lacking the number feature entirely. I will return to the discussion of the two possible accounts at the end of this section.

Now consider the contrast in (18)-(19), which shows that only definite-declension genitives can trigger possessive agreement.

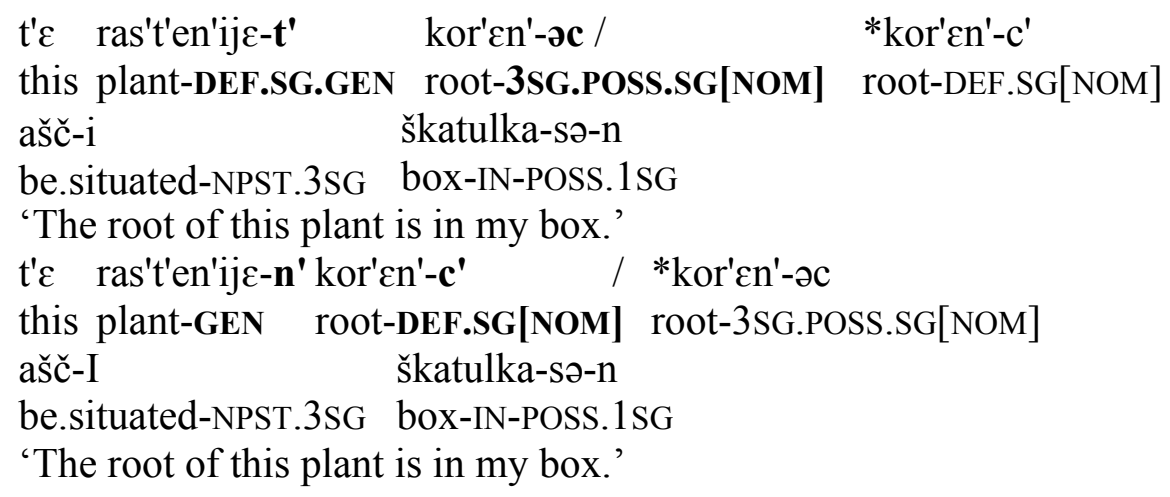

Following Chomsky's (2000) probe-goal architecture of agreement, I model agreement in possessive phrases as follows: the Poss head looks for some element with the features of person and number. When it reaches a DP in the domain of its search, it copies the features from that DP; this is what happens in (18).

Before I proceed with the analysis, I would like to return to the question whether the absence of overt number marking in the indefinite-declension genitive is simply an accident of morphology or whether it reflects the underlying syntactic structure.

As I mentioned above, one of the options is to account for the absence of overt number marking in a purely morphological analysis. On this approach, the nominal is always a DP with a valued number feature and a genitive case feature. Such a situation is by no means exotic. Consider example (20) from English, where the subject DPs in (20a) and (20b) have number features and trigger agreement on the predicate, but the surface form happens to be the same.

(20) English

a. The sheep is grazing.

b. The sheep are grazing.

Number syncretism in the Moksha indefinite declension could be captured by the framework of Distributed Morphology (DM; Halle \& Marantz 1993, a.o.), where certain features do not get lexicalized due to Underspecification or Impoverishment. Underspecification would mean that lexical items available in the vocabulary are not specified for number. Therefore, a node with any number features would be lexicalized with the same vocabulary item $\left(-n^{\prime}\right)$. Impoverishment, on the other hand, would (post-syntactically) delete number features in presence of some other feature. Without going further into details, I assume that this purely morphological syncretism is possible to model given the tools of the DM framework. The only concern here is that the DPs that will receive different marking must have different features. It is unclear which feature would allow for the insertion of more specified definite-declension markers or which feature would trigger Impoverishment. As the data show, neither specificity nor definiteness would work here, so the responsible feature has to be stipulative. 
The problem of the "ghost feature" stipulated in the morphological account also affects the explanation of the agreement pattern. Agreement is a syntactic operation as proposed by Chomsky (2000). As also observed by Preminger (2014), even if agreement seems to track morphological case (as first noticed by Bobaljik 2008), it still must operate in narrow syntax. Even in a most "superficial" account, in which following Bobaljik, we assume that agreement is a post-syntactic operation sensitive to feature bundles on the nodes lexicalized by morphemes, we still need to refer to some feature that is present in one genitive morpheme and absent in the other. Moreover, as I show in section 4.2., in some instances, the genitive $-n^{\prime}$ appears on nominals that do trigger agreement. If the agreement probe looks for a feature bundle that is not lexicalized as $-n^{\prime}$, then it is unclear why in some cases it still sees a feature bundle that is lexicalized as $-n^{\prime}$.

Therefore, an attempt to maintain a uniform syntactic structure and establish a purely morphological explanation of the facts runs into problems with adding stipulative features and needing to account for the inconsistencies in agreement. If we depart from the assumption that the nominals are uniformly DPs and accept the idea that they can be of different structural size, the agreement pattern and different lexicalization of the morphemes naturally follow. I turn to the syntactic account in the next section.

4. Analysis and its predictions. As I have shown so far, the referential characteristics of a noun phrase do not determine its marking. Specificity and definiteness do not necessarily entail definite-declension marking. Furthermore, in contrast to their definite-declension counterparts, indefinite-declension genitives fail to express number or trigger possessive agreement.

I argue that these contrasts reflect a difference in the underlying structure of definite- and indefinite-declension genitives. A full DP has the structure represented in Figure 2.

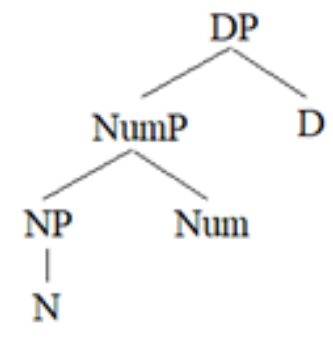

Figure 2. A full DP structure

The genitive marking found with definite-declension nominals expones the features on the higher, functional nodes: number, [D], and Case, cf. $-t^{\prime}$ for singular genitive DPs, and $-t^{\prime} n ' \partial n^{\prime}$ for plural genitive DPs.

The small nominals discussed here lack the NumP and DP layers (i.e., they are NPs). The reason why number is not distinguished in the indefinite declension is that indefinite-declension phrases lack the NumP layer, which would bear that feature. The absence of DP in the functional structure also explains the absence of possessive agreement. In (19), the probe encounters the NP ras't'en'ije-n', which lacks the DP layer and does not have [D] features; the probe does not see this NP, and no agreement is possible.

My analysis predicts that indefinite-declension genitives should not be expected to demonstrate properties that would be characteristic for DPs. Assuming that $-n^{\prime}$-marked nominals are not DPs, whereas nominals marked with $-t^{\prime} / t^{\prime} n^{\prime} \partial n^{\prime}$ are DPs, we can make further predictions about their distribution. These predictions are based on two theory-internal considerations which I will elaborate on in sections 4.1 and 4.2. First, there is a restriction against two DPs co-occurring in 
“close quarters" (Alexiadou \& Anagnostopoulou 2001; Richards 2006). Second, it is unclear how one and the same (genitive) case is assigned to two DPs within one domain within the configurational theory of case adopted here. Based on these considerations, we can make a prediction that noun phrases with two nominal dependents marked with $-t^{\prime} /-t^{\prime} n^{\prime} \partial n^{\prime}$ must be ungrammatical. On the other hand, noun phrases where at least one of the nominals is marked with $-n^{\prime}$ are expected to be grammatical. Likewise, two $-n^{\prime}$-marked nominals should be possible within one noun phrase, because they are not DPs and are not subject to the constraints just mentioned. Let us now discuss these predictions in more detail.

4.1. THE BAN ON TWO DPS. In their discussion of VP structures, Alexiadou and Anagnostopoulou (2001) observe that when two DP arguments originate within a VP, one of them must move. This can be seen from the transitivity restriction in English Quotative Inversion, (21). The placement of the quantifier all shows that under inversion, the subject is in situ (21b), as only in situ subjects can appear to the right of floating quantifiers (Sportiche 1988). Furthermore, this subject cannot be moved and placed to the left of the quantifier, (21c). On the other hand, in absence of inversion, the subject moves and appears to the left of the quantifier, (21a).

(21) English (Alexiadou \& Anagnostopoulou 2001: 197)

a. "We must do this again," the guests all declared to Tony.

b. "We must do this again," declared all the guests to Tony.

c. *"We must do this again," declared the guests all to Tony.

Alexiadou and Anagnostopoulou use these data to motivate a generalization whereby "by SpellOut VP can contain no more than one argument with an unchecked Case feature" (ibid: 216$){ }^{6}$ Richards (2006) discusses the same phenomenon arguing that this restriction is due to linearization constraints, not case checking. No matter what the reason for this constraint is, we do not expect to see two DPs very close to each other, structurally speaking. ${ }^{7}$

The prediction is therefore clear; we do not expect two nominals in the definite-declension genitive (two DPs) within one enclosing noun phrase. At the same time, there should be no restrictions on the co-occurrence of a nominal marked with a definite genitive and a nominal marked with an indefinite genitive. Nor do we expect any restrictions on two indefinite-declension nominals. These predictions are borne out. In (22), we see that two $t^{\prime}$-marked noun phrases are incompatible. Meanwhile, $n^{\prime}$-marked noun phrases can co-occur within the same noun phrase, (23) and (24).

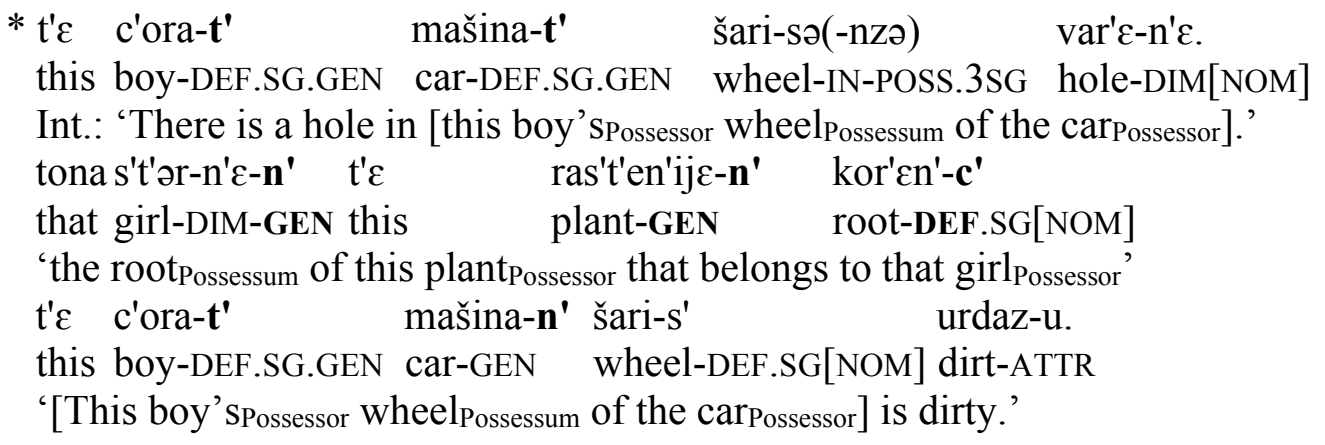

\footnotetext{
${ }^{6}$ In their analysis, case is assigned under agreement, which is different from what is assumed in this paper. However, the gist of the argument does not change with the change of case-licensing model.

${ }^{7}$ In both cited works closeness is understood in terms of phase boundaries. There should be at least one phase boundary between the two DPs.
} 
Example (23) raises an interesting question for Richards's (2006) theory. The main point of his explanation is that the constraint operates during the linearization process, and what matters is similarity / distinctness of the objects that must be linearized within a phase. In this respect, two NPs should not be different from two DPs, yet we see the contrast between ungrammatical (22) and grammatical (23). If Richards is right, then we must say that the two NPs appear in different phases, e.g. the higher NP is on the phase edge. The same configuration must be ruled out, however, with two DPs, presumably because they both raise to the higher phase. Otherwise, the ban on co-occurrence of two DPs must operate in narrow syntax and be related to case. I leave the resolution of this issue for future research. What is important at this juncture is that the co-occurrence possibilities of indefinite- and definite-declension genitives are different.

4.2. DPS AS CASE COMPETITORS. I assume that case is assigned configurationally, which means that when two DPs occur within enclosing domain, at most one of them can receive unmarked case. There is no dependent case assignment within the nominal domain (at least in Moksha). Either of the two adnominal dependent marking strategies works in a context with only one adnominal dependent. Given what I showed in the previous subsection, the conflict never arises: two DPs cannot co-occur within the nominal domain, in the first place. But that begs the question as to why small nominals (NPs) that do not need case are marked with genitive. The marking of small nominals for case is problematic because it is unclear where in their structure, the case feature could be placed.

I argue that the marker $-n^{\prime}$, which is traditionally called the genitive of the indefinite declension, is not a case marker at all, but rather the exponence of caseless NPs. Caseless NPs do not participate in case competition and can co-occur in the same domain, as shown in (24) above.

While the DP-NP distinction solves the problem of two genitives, it does not account for all the instances of the marker $-n^{\prime}$ in Moksha. In particular, there are four contexts in which $-n^{\prime}$ appears on DPs: (i) as part of the plural genitive marker $-t^{\prime} n^{\prime} \partial n^{\prime}(25)$; (ii) as part of possessive genitives (26); (iii) genitive marking personal names (27); and (iv) genitive marking pronouns (28). The morphosyntactic properties of $-n^{\prime}$-marked forms in (i)-(iv) are DP properties. In (25), the definite-declension genitive is unambiguously plural due to the definite plural marker $-t^{\prime} n^{\prime} \partial$, which precedes $-n^{\prime}$; in addition to that, there is possessive agreement on the head noun 'house'. A very similar pattern is observed in (26), where the possessive marker $-z^{\prime}$ ' preceding $-n$ ' indicates that the noun phrase is unambiguously singular, encoding not only the $\varphi$-features of the possessor (1SG) but also the number of possessum (SG). Again, we see possessive agreement on the head noun 'armchair'. Likewise, the lack of ambiguity and possessive agreement on the head are observed in (27) and (28).

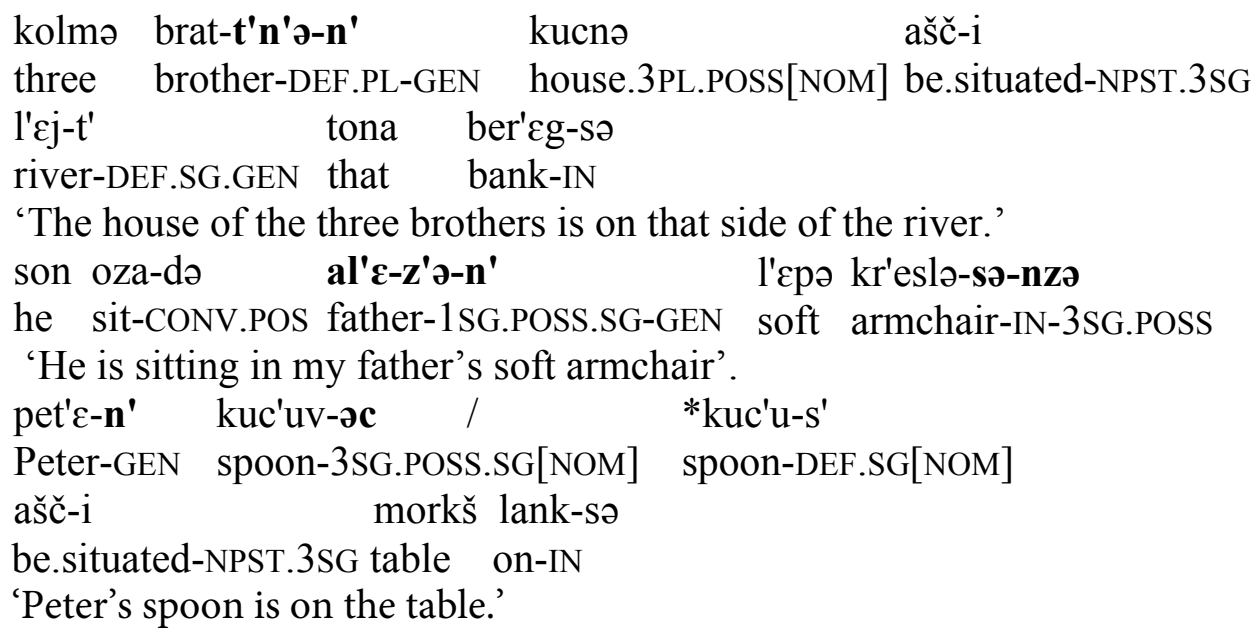


t'E-n' ečkə ronk-sə-nzə pizə

this-GEN thick trunk-IN-POSS.3SG hollow

'There is a hollow in its [the tree's] thick trunk.'

If my proposal to treat the indefinite-declension marker $-n^{\prime}$ as the exponence of caseless NPs is on the right track, I have to postulate a different instance of $-n^{\prime}$, in order to account for the occurrence of an $-n^{\prime}$ on DPs. But the need for two different $-n^{\prime}$ exponents, each with different properties, does not invalidate the account developed here. To put it simply, it is possible that Moksha has two $-n^{\prime}$ morphemes; one is the exponent of the genitive case, the other one marks caseless NPs. A slightly more complicated alternative can be modelled using e.g. the DM framework. On this approach, $-n^{\prime}$ is a single nominal dissociated morpheme, i.e., it is not present in the narrow syntax and added at the morphological level (Embick 1997). This nominal morpheme satisfies a language-internal requirement on impossibility of bare nominals. The nominal morpheme is contextually dependent on the other nominal features, which results in forms like $-s^{\prime}$ (DEF, SG, NOM) or $-t^{\prime}$ (DEF, SG, -NOM). The exponent $-n^{\prime}$ serves as the elsewhere form, which lexicalizes both caseless forms and genitive forms in the absence of a more specified context.

5. Conclusions and theoretical implications. In this paper I examined the marking of Moksha genitives and showed that their traditional characterization as definite or indefinite is misleading. The choice of an indefinite- or definite-declension form does not depend on referential characteristics of the noun phrase. Some definite noun phrases cannot be marked by a definite-declension genitive. At the same time, specific definite noun phrases can appear in the indefinite declension.

I argue that instead of placing the difference between the declensions in semantics, we need to examine the syntactic properties of the relevant noun phrases. What we see is that noun phrases with different marking have different syntactic properties. Indefinite-declension genitives show number neutrality, while definite-declension genitives are specified for number. In contrast to the former, the latter also trigger possessive agreement on the head noun. The difference is easily explained if indefinite-declension forms are small nominals that lack NumP and DP, where number and agreeing features are located. Definite-declension forms are DPs and include a NumP, so they are specified for number and are visible to the agreement probe.

Therefore, morphology reflects the underlying syntactic structure, and the marking depends on the structural size of the nominal.

The analysis of indefinite-declension genitives as NPs that lack the NumP layer makes clear semantic predictions. If the number feature is absent in their structure, they must be interpreted as generic or vague with respect to number. If indefinite-declension genitives are DPs and are syncretic only at the surface level, they must be interpreted as ambiguous. Finding out what wins, vagueness or ambiguity, is a question for future research.

If my analysis is on the right track, Moksha provides an example of a language where nominals of different structural size can coexist. Moreover, this structural difference is encoded in overt morphology, unlike Russian, where Pereltsvaig (2006) has argued that small nominals and full DPs coexist but have the same morphological marking.

The Moksha data discussed here suggest that structural reduction in the nominal domain is not something marginal or unusual. For example, small nominals are used to avoid two co-occurring DPs in those syntactic (or linear) configurations where such co-occurrence is banned. Moksha allows us to formulate further questions related to the nature of this ban. If the linearization-related ban on the occurrence of $\langle\alpha, \alpha\rangle$ structures, formulated by Richards, is correct, then 
why is it only $<\mathrm{DP}, \mathrm{DP}>$ sequences that are ruled out by the grammar, and not $<\mathrm{NP}, \mathrm{NP}>$ ? The latter seems to be grammatical in Moksha, based on the data shown above.

We do not know enough to state decisively that all languages allow small nominals. Moreover, the distribution of small nominals does not seem to be restricted to the position of nominal dependents (Pereltsvaig 2006; Lyutikova \& Pereltsvaig 2015). Determining all possible structural positions where small nominals can occur, as well as language-specific restrictions on such small nominals, could shed light on the internal hierarchical structure of the noun phrase and on subcategorization principles.

\section{References}

Abney, Steven. 1987. The English noun phrase in its sentential aspect. Cambridge, MA: MIT dissertation.

Alexiadou, Artemis \& Elena Anagnostopolou. 2001. The subject-in-situ generalization and the role of case in driving computations. Linguistic Inquiry 32(2). 193-231. https://doi.org/10.1162/00243890152001753.

Alexiadou, Artemis, Liliane Haegeman \& Melita Stavrou (eds.). 2007. Noun phrase in the generative perspective. Berlin: Mouton de Gruyter.

Bobaljik, Jonathan. D. 2008. Where's phi? Agreement as a post-syntactic operation. In David Adger, Daniel Harbour \& Susana Bejar (eds.), Phi-theory: Phi features across interfaces and modules, 295-328. Oxford: Oxford University Press.

Bošković, Zeljko. 2008. What will you have, DP or NP? Proceedings of NELS 37. 01-114.

Chomsky, Noam. 2000. Minimalist inquiries: The framework. In James R. Martin, David Michaels \& Juan Uriagereka (eds.), Step by step: Essays on minimalist syntax in honor of Howard Lasnik. 89-155. Cambridge, MA: MIT Press.

Embick, David. 1997. Voice and the interfaces of Syntax. Philadelphia, PA: University of Pennsylvania dissertation.

Evsevjev, Makar E. 1963. Izbrannye trudy [Selected works]. Vol. 4. Osnovy mordovskoj grammatiki [The basics of the Mordvin grammar]. Saransk: Mordovskoe kžnoe izdateljstvo. ( $1^{\text {st }}$ ed. - 1929.) (In Russ).

Feoktistov, Aleksandr P. 1975. Mordovskie jazyki [The Mordvinic languages]. In Vasilij I. Lytkin et al. (eds.), Osnovy finno-ugorskogo jazykoznanija 2. Pribaltijsko-finnskie, saamskij i mordovskie jazyki [The basics of the Finno-Ugristics 2. The Baltic Finnic, Saam and Mordvinic languages], 248-343. M.: Nauka. (In Russ).

Halle, Morris \& Alec Marantz. 1993. Distributed Morphology and the pieces of inflection. In Kenneth L. Hale \& Samuel J. Keyser (eds.), The view from Building 20: Essays in linguistics in honor of Sylvain Bromberger. 111-176. Cambridge, MA: MIT Press.

Kholodilova, Maria A. 2018. Morfologija imeni [Nominal morphology]. In Svetlana J. Toldova et al. (eds.), Elementy mokshanskogo jazyka v tipologicheskom osveschenii [Elements of the Moksha language in typological perspective]. 63-121. M.: Buki Vedi. (In Russ).

Koljadenkov, Mikhail N. \& R. A. Zavodova (eds.). 1962. Grammatika mordovskikh (mokshanskogo i erzjanskogo) jazykov. Chastj I. Fonetika I morfologija [Grammar of the Mordvinic (Moksha and Erzya) languages. Part I. Phonetics and morphology]. Saransk: Mordovskoe knizhnoe izdateljstvo. (In Russ). 
Lyutikova, Ekaterina \& Asya Pereltsvaig. 2015. The Tatar DP. The Canadian Journal of Linguistics/La revue canadienne de linguistique (60(3). 289-325. https://doi.org/10.1017/S0008413100026232.

Marantz, Alec. 1991. Case and licensing. In Germán F. Westphal, Benjamin Ao, and Hee-Rahk Chae (eds.), Eastern States Conference on Linguistics. 234-253. Ithaca, NY: CLC Publications.

Pereltsvaig, Asya. 2006. Small nominals. Natural Language \& Linguistic Theory 24(2). 433500. https://doi.org/10.1007/s11049-005-3820-z.

Plaksina, Tamara A. 2002. Arealjnoe issledovanie severo-zapadnykh govorov moksha-mordovskogo jazyka [Areal study of North-Western varieties of the Moksha-Mordvin langiage]. Saransk: MGPI im. M. E. Evsevjeva dissertation. (In Russ).

Pleshak Polina \& Maria Kholodilova. 2018. Imennaja gruppa [Noun phrase.] In Svetlana J. Toldova et al. (eds.), Elementy mokšanskogo jazyka v tipologičeskom osveščenii [Elements of the Moksha language in typological perspective]. 272-310. M: «Buki Vedi». (In Russ).

Preminger, Omer. 2014. Agreement and its failures. Cambridge, MA: MIT Press.

Simonenko, Alexandra. 2017. Towards a semantic typology of specific determiners. Amsterdam Colloquium 21. 425-434.

Sportiche, Dominique. 1988. A theory of floating quantifiers and its corollaries for constituent structure. Linguistic inquiry 19(3). 425-449.

Toldova, Svetlana J. 2017. Kodirovanie prjamogo dopolnenija v Mokshanskom jazyke [Direct object encoding in the Moksha language]. ACTA LINGUISTICA PETROPOLITANA. Transactions of the Institute for Linguistic Studies, Russian Academy of Sciences XIII (3). 123157. St. Petersburg: Institute for Linguistic Studies, Russian Academy of Sciences.

Toldova Svetlana J. 2018. Differencitovannoe kodirovanie prjamogo dopolnenija [Differential direct object encoding]. In Svetlana J. Toldova et al. (eds.), Elementy mokšanskogo jazyka $v$ tipologičeskom osveščenii [Elements of the Moksha language in typological perspective]. 574-608. M: «Buki Vedi».

Toldova, Svetlana J., Maria A. Kholodilova, Sergei G. Tatevosov, Egor V. Kashkin, Alexei A. Kozlov, Lev S. Kozlov, Anton V. Kukhto, Maria J. Privizentseva, Ivan A. Stenin (eds.). 2018. Elementy mokšanskogo jazyka v tipologičeskom osveščenii [Elements of the Moksha language in typological perspective]. M: «Buki Vedi». 